\title{
Ochratoxin A in nephropathic patients from two cities of central zone in Portugal
}

\author{
A.M.P. Dinis, C.M. Lino*, A.S. Pena \\ Group of Bromatology-CEF, Faculty of Pharmacy, University of Coimbra, 3000 Coimbra, Portugal \\ Received 31 October 2006; received in revised form 28 November 2006; accepted 1 December 2006 \\ Available online 8 January 2007
}

\begin{abstract}
Ochratoxin A (OTA) produced by Aspergillus and Penicillium genera contaminates several foods. OTA is nephrotoxic to all animal species studied so far, and most likely to humans, who show the longest half-life for elimination of this toxin among all examined species. OTA has other toxic effects such as teratogenicity, immunotoxiity, genotoxicity, and is also mutagenic and carcinogenic, all of which lead to life-threatening pathologies through several molecular pathways.

A sensitive, specific and rapid method applying high performance liquid chromatography coupled to a spectrofluorimeter for the determination of ochratoxin A in human serum was validated. Serum samples were extracted with chloroform-orthophospohric acid, and cleaned-up through immunoaffinity column (IAC). The separation and identification was performed by HPLC coupled to a spectrofluorimeter, and, after OTA methylation, the confirmation was achieved. Chromatographic separation of the analyte was performed on a reverse phase column with a mobile phase of water:acetonitrile:glacial acetic acid (49.5:49.5:1.0). Linearity was established between the range of 1 and $10 \mathrm{ng} / \mathrm{ml}$. Under the optimized conditions, the recoveries were higher than $83.0 \%$ for all fortification levels. The intra-day precision oscillated between 8.0 and $5.0 \%$ at levels of 0.25 and $0.5 \mu \mathrm{g} / \mathrm{l}$, while the inter-day precision was in the range of $10.7-16.0 \%$. The limit of quantification of the method was $0.05 \mu \mathrm{g} / \mathrm{l}$. The method is appropriate for quantitative determination of OTA in human serum and has been successfully applied to the analysis of OTA in haemodialysis patients from two principal cities of Portugal, in order to evaluate its exposure degree.

Levels of OTA in Coimbra were higher than in Aveiro, $0.50 \mu \mathrm{g} / \mathrm{l}$ versus $0.49 \mu \mathrm{g} / \mathrm{l}$. In respect to gender, levels of OTA were higher in males from Aveiro than in females, $0.52 \mu \mathrm{g} / \mathrm{l}$ versus $0.44 \mu \mathrm{g} / \mathrm{l}$, and in Coimbra were similar, $0.50 \mu \mathrm{g} / \mathrm{l}$ versus $0.51 \mu \mathrm{g} / \mathrm{l}$. However, in none of the cases, significant statistical differences were found.
\end{abstract}

(C) 2006 Elsevier B.V. All rights reserved.

Keywords: Ochratoxin A; HPLC-spectrofluorimeter; Human serum; Coimbra; Aveiro

\section{Introduction}

Ochratoxin A (OTA) is a mycotoxin produced by several Aspergillus and Penicillium species. Among Aspergillus species there are two in section Nigri and four in section Circumdati, formerly the Aspergillus ochraceus group, now referred to as Aspergillus alutaceus [1-3]. The presence of OTA in human blood or serum is related with contaminated food ingestion. Penicillium verrucosum and Aspergillus species have been consistently associated with cereals and coffee beans, respectively. Aspergillus niger and carbonarius have been isolated from dried vine fruit $[1,4]$. Other food items, such as milk [5], animal tis-

\footnotetext{
* Corresponding author. Tel.: +351 239859994; fax: +351 239827126 .

E-mail address: cmlino@ci.uc.pt (C.M. Lino).
}

sues, muscle, organs, and eggs $[2,3,6]$, pulses, wine and beer [1,7-9] have also been contaminated.

Recognized as carcinogenic, teratogenic, immunotoxic, genotoxic, as well nephrotoxic [1-3,9], the evaluation of OTA levels in different type of populations is unquestionable to provide data about exposure and evaluate the possible human health risk of OTA.

Only few studies carried out in Europe [10-12], and Africa [13-16] reported the possible connection between the presence of OTA in human serum and nephropathy. Investigations in different countries have shown that OTA occurs in nephropathy patients with different mean concentrations in blood. These levels oscillated between $0.34 \mu \mathrm{g} / 1$, in Egypt [15] and $85.3 \mu \mathrm{g} / \mathrm{l}$, in Tunisia [17].

The aim of this work was validate one hyphenated technique using HPLC coupled to a spectrofluorimeter for the 
determination of OTA levels in serum, and to evaluate, at the first time, the exposure of two populations undergoing haemodialysis from the central zone of Portugal, Coimbra and Aveiro. Mean concentrations of OTA in both genders were also studied in the two analysed populations. The OTA identity was confirmed by methyl ester formation.

\section{Experimental}

\subsection{Sampling and description of populations}

The study was carried out in 2003 in the two most important cities of the central region of Portugal, Coimbra and Aveiro, far from each one another $60 \mathrm{~km}$. OTA serum levels were evaluated in 95 donors undergoing haemodialysis, 50 from Coimbra (27 mens and 23 womens) and 45 from Aveiro ( 26 mens and 19 womens). Blood samples were collected in November/December 2002 and September 2003 in Coimbra and Aveiro, respectively. The donors enrolled in this study were all volunteers, clearly informed and fully consenting.

In Coimbra and Aveiro the mean donor age was $66 \pm 14$, and $56 \pm 15$, respectively, while the mean weights were $66 \pm 13$ and $65 \pm 13$.

Blood samples were collected in glass tubes $(50 \mathrm{ml})$, and the serum samples were obtained by heating the tubes at $37^{\circ} \mathrm{C}$ for $3 \mathrm{~h}$, and submitting them to centrifugation at $1510 \times \mathrm{g}$ for $10 \mathrm{~min}$.

\subsection{Reagents}

HPLC grade acetonitrile, chloroform, toluene, and methanol were purchased from Carlo Erba (Milan, Italy). Acetic acid, hydrochloride acid, sodium hydroxide, potassium chloride, potassium dihydrogenphosphate, anhydrous disodium hydrogenphosphate, sodium hydrogencarbonate, sodium chloride, and $85 \%$ orthophosphoric acid were obtained from Merck (Darmstadt, Germany). Water was purified by distillation and passage through a Milli-Q system (Millipore, Bedford, MA, USA). OTA with purity grade $\geq 98 \%$, and a boron trifluoride $14 \%$ methanolic solution were purchased from Sigma Chemical Co. (St. Louis, MO, USA).

Imunoaffinity columns Ochratest ${ }^{\mathrm{TM}}$ IAC were from VICAM (Watertown, USA).

\subsection{Preparation of stock and standards solutions}

A standard solution of OTA was prepared from the OTA vial purchased from Sigma. The standard stock solution was made in $4 \mathrm{ml}$ toluene:acetic acid (99:1) at $250 \mu \mathrm{g} / \mathrm{ml}$, and stored at $-20{ }^{\circ} \mathrm{C}$. An intermediate standard solution was prepared at $10 \mu \mathrm{g} / \mathrm{ml}$, by diluting $1 \mathrm{ml}$ of stock standard solution with $25 \mathrm{ml}$ toluene:acetic acid (99:1). For fortification assays, a standard solution was prepared in toluene:acetic acid (99:1) at $1 \mu \mathrm{g} / \mathrm{ml}$.

For the calibration curve, standard solutions were prepared by evaporating $10 \mu \mathrm{l}$ of stock solution to dryness, and diluting to $10 \mathrm{ml}$ with mobile phase. After suitable dilutions in water:methanol:acetic acid (49.5:49.5:1), the working standard solution was used to prepare the external calibration curve $(1,2$, 5 , and $10 \mathrm{ng} / \mathrm{ml})$.

\subsection{Analysis of ochratoxin A}

\subsubsection{Extraction and clean-up}

Two milliliter of serum added with $10 \mathrm{ml}$ of a solution containing $33.7 \mathrm{ml}$ of $85 \%$ orthophosphoric acid and $118 \mathrm{~g}$ sodium chloride per liter, were vortex mixed for $1 \mathrm{~min}$. Afterwards, $2 \times$ $5 \mathrm{ml}$ of chloroform were added, and after an intensive vortex mixing for $3 \mathrm{~min}$ it was centrifuged at $2485 \times g$ for $15 \mathrm{~min}$. The organic phase was evaporated to dryness at $30-40{ }^{\circ} \mathrm{C}$. The dry extract was dissolved in $5 \mathrm{ml}$ of PBS-methanol and passed through IAC column. This procedure was repeated three times. After passage of the solution, the column was washed with water and dried by air. OTA was then eluted with $3 \mathrm{ml}$ methanol, and evaporated to dryness at $30-40{ }^{\circ} \mathrm{C}$ under a gentle steam of $\mathrm{N}_{2}$. The concentrated residue was dissolved in $250 \mu \mathrm{l}$ of mobile phase and injected in the HPLC system.

\subsubsection{Detection and quantification}

For detection an HPLC system consisting of a pump, model 307 (Gilson, France), one $20 \mu$ l injection valve, model 7125 (Rheodyne, Cotati, California, USA), a guard column, $\mathrm{C}_{18}$ $0.5 \mu \mathrm{m}$ Nucleosil $120 \mathrm{KS}(30 \mathrm{~mm} \times 4 \mathrm{~mm}$ i.d. $)$, and a column, $\mathrm{C}_{18} 5 \mu \mathrm{m}$ Nucleosil 100 (250 $\mathrm{mm} \times 4.6 \mathrm{~mm}$ i.d.) was used. A spectrofluorimeter, model LS-45 (Perkin-Elmer, USA) was coupled to the HPLC, and the analyses were made using $333 \mathrm{~nm}$ for excitation and $460 \mathrm{~nm}$ for emission. An integrator, model $3390 \mathrm{~A}$ (Hewlett-Packard), was used to measure peak areas.

The mobile phase consisted of a mixture of water: acetonitrile:glacial acetic acid (49.5:49.5:1.0) at a flow rate of $1 \mathrm{ml} / \mathrm{min}$.

\subsubsection{Validation studies}

Linearity was evaluated in the range of $0.02-0.2 \mathrm{ng}$ (1-10 ng/ml).

The recovery studies were made by adding OTA standard solution, prepared in toluene:acetic acid (99:1), to three replicates of serum. For these studies, $0.5,1.0$ and $2.0 \mathrm{ng}$ of OTA, equivalent to fortification levels of $0.25,0.5$ and $1.0 \mathrm{ng} / \mathrm{ml}$, respectively, were added to $2 \mathrm{ml}$ serum, and allowed to stand for $15 \mathrm{~min}$ at room temperature before extraction (Table 1).

\subsection{Confirmation}

Sample extracts were evaporated to dryness under $\mathrm{N}_{2}$ stream, $150 \mu \mathrm{BF}_{3}$ (14\% methanolic solution) were added, and the

Table 1

Data for accuracy and intra- and inter-assay validation $(n=3)$

\begin{tabular}{lcll}
\hline $\begin{array}{l}\text { Fortification } \\
\text { level }(\mu \mathrm{g} / \mathrm{l})\end{array}$ & $\begin{array}{l}\text { Recovery } \\
\text { mean }(\%)\end{array}$ & $\begin{array}{l}\text { RSD intra-day } \\
(\%)\end{array}$ & $\begin{array}{l}\text { RSD inter-day } \\
(\%)\end{array}$ \\
\hline 0.25 & 83 & 8.0 & 10.7 \\
0.5 & 114 & 5.0 & 12.0 \\
1.0 & 86 & 5.3 & 16.0 \\
\hline
\end{tabular}


mixture was left at $60^{\circ} \mathrm{C}$ for $10 \mathrm{~min}$. After evaporation under $\mathrm{N}_{2}$, the residue was dissolved in $150 \mu \mathrm{l}$ water:acetonitrile:glacial acetic acid (49.5:49.5:1.0). The OTA methyl esters were analysed according to the HPLC method described above.

\subsection{Statistical analysis}

Database management and statistical analysis were performed with the SPSS 10.0 Microsoft version. The differences in the OTA levels between different populations were tested with the Kruskal-Wallis test. $P \leq 0.05$ (two-tailed) was considered to be statistically significant.

\section{Results and discussion}

The calibration curve was obtained using the linear leastsquares regression procedure of the peak area versus the concentration. OTA linearity, in the working standard solutions at three determinations of four concentration levels, between 1 and $10 \mathrm{ng} / \mathrm{ml}$, namely $1,2,5$, and $10 \mathrm{ng} / \mathrm{ml}$, was good as shown by the fact that the correlation coefficient $\left(r^{2}\right)$ was 0.9998 .

In respect to the extraction procedure, good results were achieved by the use of chloroform, after addition of orthophosphoric acid and sodium chloride, similarly to the extraction ochratoxin A in muscle [6]. For serum samples, best accuracy results were obtained when sodium hydrogen carbonate solution was substituted by sodium chloride. More laborious and complex extraction procedures are usually reported. These methods generally involve dilution with magnesium chloride and chloridric acid and extraction with chloroform $[1,10,14,15]$. Some of them involve even more complexity, because the residue is suspended in methanol following dilution with Tris/chloridric or sulphuric acid buffer at $\mathrm{pH} 7.5$, before the clean-up procedure $[1,14]$. Depending on the extracts, some cleanup procedures have been tried, but, owing to its specificity, the use of immunoaffinity columns (IAC) for serum or plasma has been documented $[14,16]$. Solid-phase extraction with C18 adsorbent $[13,17,18]$ and liquid partition with sodium hydrogen carbonate have been also used [15]. Detection and quantification are usually made by liquid chromatography with fluorescence detection $[1,13,17,18]$.

The HPLC method proposed, previously developed in our latest studies $[4,6,19,20]$ exhibits good analytical performance for OTA analysis. For fluorescence detection, a spectrum of OTA standard solution in HPLC mobile phase was obtained in order to optimize OTA detection. The maximum emission wavelength at an excitation wavelength of $333 \mathrm{~nm}$, was found to be at $460 \mathrm{~nm}$.

Comparing to other published methods involving the use of more complex mobile phases with ionic pair reagents and buffers [1,13,15-18], a simple mobile phase, consisting of a mixture of water:acetonitrile:glacial acetic acid (49.5:49.5:1.0) was used.

Accuracy and precision of the analytical methodology for all the fortification levels were adequate and in accordance to international parameters [21-23] (Table 1). Recovery values varied between 83 and $114 \%$, at levels of 0.25 and $0.5 \mu \mathrm{g} / \mathrm{l}$, respectively. The intra-day precision oscillated between 8.0 and $5.0 \%$ at levels of 0.25 and $0.5 \mu \mathrm{g} / \mathrm{l}$, while the inter-day precision was in the range of 10.7 and $16.0 \%$.

The limit of quantification was $0.05 \mu \mathrm{g} / \mathrm{l}$. According to an investigation on the LOQ obtained values from different methods used for OTA determination in blood, the results obtained herein are of the same order as those reported by Thuvander [1], are better than those reported by Jimenez et al. [10], $0.52 \mu \mathrm{g} / \mathrm{l}$, Hassen et al. [18], and by Grosso et al. [14], $0.1 \mu \mathrm{g} / \mathrm{l}$.

Fig. 1 shows representative liquid chromatographyspectrofluorimetric chromatograms obtained from an OTA standard solution, from one fortified sample serum, and from one positive sample.

This study revealed that the frequency of detection in both groups of donors was $100 \%$. However, studies in Tunisia show different occurrences, $20.5 \%$ [16], between 78 and $100 \%$ [18], between 87 and $100 \%$ [13], and $100 \%$ [14], probably due to different limits of quantification of the analytical methodology used [14].

The overall concentrations in nephropathy patients from Coimbra ranged from 0.12 to $1.52 \mu \mathrm{g} / \mathrm{l}$, being the mean concentration and standard deviation $0.50 \pm 0.29 \mu \mathrm{g} / \mathrm{l}$, and the median $0.45 \mu \mathrm{g} / \mathrm{l}$. Comparing these values with those from Aveiro population, the overall concentrations were between 0.15 and $1.03 \mu \mathrm{g} / \mathrm{l}$, the mean concentration and standard deviation were $0.49 \pm 0.22 \mu \mathrm{g} / \mathrm{l}$, and the median was $0.42 \mu \mathrm{g} / \mathrm{l}$ (Table 2). Significant differences were not found between OTA levels in the two cities $(P$-value $=0.743)$.

Comparing these results with those obtained in other countries, the levels found in nephropathy donors are similar to those found in some groups of patients in Egypt with end stage renal disease (ESRD), $0.47 \pm 1.62 \mu \mathrm{g} / \mathrm{l}$ in renal transplant recipients and $0.52 \pm 1.46 \mu \mathrm{g} / \mathrm{l}$ in patients with urothelial tumours, and are higher than $0.34 \pm 0.69 \mu \mathrm{g} / \mathrm{l}$, found in patients with ESRD under dialytic therapy. Higher values were detected in patients with ESRD under conservative medical treatment $(1.01 \pm 1.56 \mu \mathrm{g} / \mathrm{l})$ and in patients with nephrotic syndrome $(2.19 \pm 3.07 \mu \mathrm{g} / \mathrm{l})$. The highest value found in patients undergoing haemodialysis in Coimbra and in Egypt was 1.51 and $2.17 \mu \mathrm{g} / \mathrm{l}$, respectively [15]. However, in Navarra-Spain, Bari-Southern Italy, IspartaTurkey, and Abidjan-Tunisia, highest mean concentrations were detected in nephropathy patients under dialytic treatment with $1.97,1.4,2.1$, and $1.05 \mu \mathrm{g} / \mathrm{l}$, respectively, with maximum values of $11.70,5.4$, and $2.42 \mu \mathrm{g} / 1$ for Spain, Turkey, and Tunisia, respectively [10-12,16].

Levels of OTA in women and in men from Coimbra are similar, $0.51 \pm 0.28 \mu \mathrm{g} / \mathrm{l}$ versus $0.50 \pm 0.32 \mu \mathrm{g} / \mathrm{l}$, with $P=0.793$. In Aveiro, the OTA mean concentrations in men were higher,

Table 2

Minimum, maximum, mean concentration, S.D., and median of OTA $(\mu \mathrm{g} / \mathrm{l})$ in patients undergoing hemodialysis of two cities in central zone of Portugal

\begin{tabular}{llc}
\hline & Coimbra & Aveiro \\
\hline Minimum & 0.12 & 0.15 \\
Maximum & 1.52 & 1.03 \\
Mean & 0.50 & 0.49 \\
Standard deviation & 0.29 & 0.22 \\
Median & 0.45 & 0.42 \\
\hline
\end{tabular}




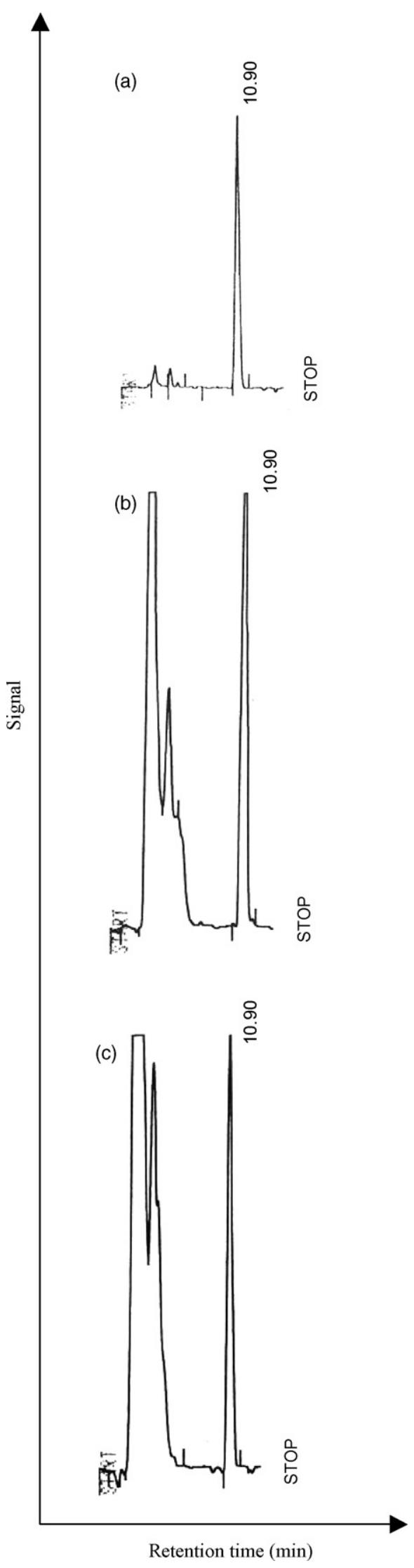

Fig. 1. Liquid chromatography-spectrofluorimetric chromatograms of ochratoxin A (OTA) standard (a) $(0.25 \mathrm{ng}$ ) (retention time $10.90 \mathrm{~min}$ ), one serum sample fortified at $0.25 \mu \mathrm{g} / \mathrm{l}$ (b), and one sample containing $0.98 \mu \mathrm{g} / \mathrm{l}$ (c).
Table 3

Mean concentration $(\mu \mathrm{g} / \mathrm{l})$, S.D., and median of OTA in women $(\mathrm{W})$ and men (M) serum in the two cities

\begin{tabular}{lllll}
\hline & Coimbra-W & Aveiro-W & Coimbra-M & Aveiro-M \\
\hline Mean & 0.51 & 0.44 & 0.50 & 0.52 \\
Standard deviation & 0.28 & 0.18 & 0.32 & 0.24 \\
Median & 0.48 & 0.39 & 0.41 & 0.41 \\
\hline
\end{tabular}

$0.52 \pm 0.24 \mu \mathrm{g} / \mathrm{l}$, than those found for women, $0.44 \pm 0.18 \mu \mathrm{g} / \mathrm{l}$. However, no significant difference was found, $P=0.265$. The median was 0.48 and $0.41 \mu \mathrm{g} / \mathrm{l}$, for women and men from Coimbra, and 0.39 and $0.41 \mu \mathrm{g} / \mathrm{l}$ for women and men from Aveiro, respectively (Table 3 ).

These occurrences may be due to different situations. One is the highest moisture grade of the different areas, and another is the probable ingestion of foods with deficient procedures of conservation. The highest consumption of alcoholic beverages, different consumption habits, and regional food intake patterns may also contribute to these differences. The climate may also be responsible for fluctuations in human exposure, because the consumed food may be contaminated at different levels under different climatic conditions [10].

In this study, the OTA mean concentration of dialysed patients, from Coimbra, was similar to that found in a previous study in healthy donors [24], $0.50 \pm 0.29 \mu \mathrm{g} / \mathrm{l}$ versus $0.41 \pm 0.17 \mu \mathrm{g} / \mathrm{l}(P=0.222)$, suggesting that OTA dialyses out of plasma into dialysis solution. This may indicate that patients undergoing hemodialysis have been exposed to contaminated foods before sampling, or have been frequently exposed because of restricted diet in relation to their nephropathy, or that normal elimination via the kidney into urine of glucuronidated metabolites is blocked. These reasons may be involved all together [16]. Blood concentrations of OTA in dialysed patients, in AbidjanTunisia, were lower than OTA in healthy blood donors [16], probably because the dialysis reduces OTA concentration in blood of nephropathy patients as previously found by Wafa et al. [15] in Egypt.

In two studied populations, the estimated daily ingestion (EDI), based in the equation of Breitholtz et al. [25], was $0.67 \mathrm{ng} / \mathrm{kg}$ b.w. per day in Coimbra (range $0.16-2.04 \mathrm{ng} / \mathrm{kg}$ b.w. per day), and $0.65 \mathrm{ng} / \mathrm{kg}$ b.w. per day in Aveiro (range $0.20-1.38 \mathrm{ng} / \mathrm{kg}$ b.w. per day). These results indicate one mean tolerable daily intake within $0.2-4.2 \mathrm{ng} / \mathrm{kg}$ b.w. per day, established by Kuiper-Goodman and Scott in 1989 [2], and below $5 \mathrm{ng} / \mathrm{kg}$ b.w., the tolerable daily intake (TDI) estimated by the Scientific Committee on Foods (SFC) of the European Union in 2002 [26]. These values are in agreement with the data of the estimated daily intake obtained by the contribution of foodstuffs in the Portugal central zone, $0.018 \mathrm{ng} \mathrm{kg}^{-1} \mathrm{~b}$. w. for muscle [6], $2.6 \mathrm{ng} \mathrm{kg} \mathrm{b.} \mathrm{w.} \mathrm{per} \mathrm{day} \mathrm{for} \mathrm{rice} \mathrm{[4],} \mathrm{and} 0.07 \mathrm{ng} / \mathrm{kg}$ b.w. for maize bred [27].

\section{Conclusions}

Levels of OTA in both studied populations are lower than to patients undergoing hemodialysis from other studied European countries. 
No significant differences were found between Coimbra and Aveiro populations, and between sexes, with $P=0.743$ and 0.630 , respectively.

Mean concentrations are also similar to that found in healthy populations studied in Coimbra, with $P$-value of 0.222 .

\section{Acknowledgements}

Besides the financial support of FCT and FEDER/POCTI, the authors thank to Cancho Dialysis Clinic and to Gambro Health Care Dialave.

\section{References}

[1] A. Thuvander, J.E. Paulsen, K. Axberg, N. Johansson, A. Vidnes, H. Enghardt-Barbieri, K. Trygg, K. Lund Larsen, S. Jahrl, A. Widenfalk, V. Bosnes, Y. Alexander, K. Hult, M. Olsen, Food Chemical Toxicol. 39 (2001) 1145 .

[2] R.R. Marquardt, A.A. Frolich, J. Anim. Sci. 70 (1992) 3968.

[3] H. Valenta, J. Chrom. A 815 (1998) 72.

[4] A. Pena, F. Cerejo, C.M. Lino, M.I. Silveira, Anal. Bioanal. Chem. 382 (2005) 1288.

[5] M.A. Skaug, I. Helland, K. Solvoll, O.D. Saugstad, Food Addit. Contam. 18 (2001) 321.

[6] E. Moreno Guillamont, C.M. Lino, M.L. Baeta, A.S. Pena, M.I.N. Silveira, J.V. Mañes, Anal. Bioanal. Chem. 383 (2005) 570.

[7] B. Berente, A. Móricz, K.H. Otta, G. Záray, L. Lékó, L. Rácz, Microchemi. J. 79 (2005) 103.

[8] M. Reinsch, A. Topfer, A. Lehmann, I. Nehls, U. Panne, Food Chem. 100 (2007) 312.

[9] J. Blesa, J.M. Soriano, J.C. Moltó, J. Mañes, J. Chromatogr. A 1054 (2004) 397.
[10] A.M. Jimenez, A.L. Cerain, E. González-Penas, J. Bello, A.M. Betbeder, E.E. Creppy, J. Toxicol. Toxin Rev. 17 (1998) 479.

[11] N. Ozçelik, A. Kosar, D. Soysal, Toxicol. Lett. 121 (2001) 9.

[12] A. Breitholtz-Emanuelsson, F. Minervini, K. Hult, A. Visconti, Nat. Toxins 2 (1994) 366.

[13] S. Abid, W. Hassen, A. Archour, H. Skhiri, K. Maaroufi, F. Ellouz, E. Creppy, H. Bacha, Hum. Experim. Toxicol. 22 (2003) 77.

[14] F. Grosso, S. Said, I. Mabrouk, J.M. Fremy, M. Castegnaro, M. Jemmali, S. Dagracci, Food Chem. Toxicol. 41 (2003) 1133.

[15] E.W. Wafa, R.S. Yahya, M.A. Sobh, I. Eraky, M.A.M. El-Gayar, A.M. Betbeder, E.E. Creppy, Hum. Experim. Toxicol. 17 (1998) 124.

[16] B. Sangare-Tigori, S. Moukha, J.H. Kouadio, D.S. Dano, A.-M. Betbeder, A. Achour, E.E. Creppy, Toxicon 47 (2006) 894.

[17] K. Maaroufi, A. Archour, A.M. Betbeder, M. Hammami, F. Ellouz, E.E. Creppy, H. Bacha, Arch. Toxicol. 69 (1995) 552.

[18] W. Hassen, S. Abid, A. Achour, E. Creppy, H. Bacha, Toxicology 199 (2004) 185.

[19] C.M. Lino, L. Baeta, A.S. Pena, I.N. Silveira, Química Nova 29 (2006) 436.

[20] A. Pena, M. Seifrtová, C.M. Lino, M.I.N. Silveira, P. Solich, Food Chem. Toxicol. 44 (2006) 1449.

[21] L. Hubner, LC-GC Int. 11 (1998) 96

[22] A.R.C. Hill, S.L. Reynolds, Analyst 124 (1999) 953.

[23] M.E. Swartz, I.S. Krull, Pharm. Technol. 22 (1998) 104.

[24] A.M. Dinis, C.M. Lino, M.L. Baeta, A.S. Pena, M.I.N. Silveira, Proceedings of 6th Encontro Química dos Alimentos. Ed. INIAP-IPIMAR/Soc. Port. Química, 1030-1035 (2003).

[25] A. Breitholtz, M. Olsen, A. Dahlback, K. Hult, Food Add. Contam. 8 (1991) 183.

[26] EU (2002), Assessment of Dietary Intake of Ochratoxin A by the Population of EU Member States (Report for SCOOP Task 3.2.7.), Available at: http://europa.eu.int/comm/food/fs/scoop/index_en.html.

[27] L.G. Silva, C. Juan, C.M. Lino, A. Pena, J. Mañes, Occurrence of Fumonisins B1 and B2 and Ochratoxin A in broa Bread. Proceedings of 8th Encontro Química dos Alimentos, Beja, Portugal. 